\title{
Resenha de Marx e Habermas: Teoria crítica e os sentidos da emancipação, de Rúrion Melo (São Paulo: Saraiva, 2013)
}

\section{Marx ou Habermas? Comentário crítico ao livro Marx e Habermas: Teoria crítica e os sentidos da emancipação, de Rúrion Melo}

\author{
Amaro Fleck ${ }^{1}$ \\ amarofleck@hotmail.com \\ (Universidade Federal de Santa Catarina, \\ Santa Catarina, Brasil)
}

DOI: http://dx.doi.org/10.11606/issn.2318-9800.v19i2p165-181

Há de se questionar se seria possível uma síntese entre os pensamentos de Karl Marx e de Jürgen Habermas, principalmente ao se levar em conta que a teoria do segundo é caracterizada por um progressivo distanciamento das teses defendidas pelo primeiro. Mas, salvo engano, não foi fornecer tal síntese o intuito de Melo ao longo de seu livro. E por isso o título pode soar ambíguo, ao menos na medida em que não fica claro o significado da conjunção "e". Neste caso, como o autor não busca desenvolver uma teoria crítica que concilie aspectos de ambos os pensadores, mas muito mais afirmar a atualidade e pertinência do segundo frente a uma suposta obsolescência e esterilidade do primeiro (exceto, claro, pelo pouco da teoria marxiana que é preservada na habermasiana, que consiste mais em certo anseio emancipatório comum do que em qualquer convergência em termos de conteúdo ou de diagnóstico), penso que se deve entender tal conjunção antes no sentido pouco usado da contraposição do que naquele usual do complemento.

$\mathrm{Na}$ verdade, a obra aqui resenhada é um livro ambicioso, uma vez que pretende operar concomitantemente em distintos níveis. Por um lado, almeja mostrar os desenvolvimentos da teoria crítica - desde

1. Agradeço os comentários e críticas de Alessandro Pinzani e Denílson Werle. 
seus primórdios com a obra marxiana até os desdobramentos pós- habermasianos da autodenominada terceira geração -, por outro, tenta discutir as tarefas atuais desta corrente de pensamento cujo maior desafio é renovar os seus diagnósticos de época, como bem salienta Melo. Tal meta é buscada tanto no plano, por assim dizer, mais geral, no qual analisa o processo de modernização da sociedade capitalista, quanto em um plano paroquial, ao discutir nuances da recepção brasileira desta tradição crítica e presumidos impasses que caracterizariam seu estágio atual. Com isso, a obra tenta intervir na discussão nacional ao mostrar uma senda que seria, segundo Melo, profícua, mas que tem enfrentado certa resistência entre nós, a saber: aquela contida na teoria habermasiana e desenvolvida também por teóricos posteriores bastante influenciados por ele, tais como Jean Cohen, Axel Honneth e Seyla Benhabib. Neste comentário, gostaria de apresentar de forma sucinta a argumentação de Melo para, depois, tecer três críticas a ela.

\section{A resenha}

O livro aqui tratado é composto por três partes. As duas primeiras tratam do dilema "reforma ou revolução", a primeira apresentando a vertente revolucionária inspirada no pensamento marxiano e os impasses desta, e a segunda a corrente reformista, também inspirada no pensador socialista, e suas dificuldades. A terceira parte, que pode ser considerada propositiva, busca mostrar uma alternativa a este dilema paralisante que estaria, na visão do autor, solapando a capacidade crítica das teorias que não se conformam com o estado existente das coisas.

Antes de tratar das duas primeiras partes convém apresentar o ideal de sociedade emancipada que seria comum tanto à tradição revolucionária quanto à reformista, ideal este presente na obra de Marx. De acordo com Melo, a sociedade emancipada seria para Marx uma "República do trabalho", uma "auto-organização holista dos trabalhadores" na qual o "trabalho heterônomo" seria transformado em "trabalho autônomo". A fundamentação normativa deste ideal se encontraria subjacente ao próprio conceito de trabalho, de modo que tal concepção fica presa ao "paradigma produtivista" e ao "economicismo", pois compreende todas as relações sociais pelo prisma das relações produtivas e vê a política como mero epifenômeno dos antagonismos econômicos. Melo critica o suposto reducionismo da concepção de práxis marxiana, restrita ao trabalho, e argumenta que isto fez com 
que Marx não entendesse a emancipação "como um processo intersubjetivo, aberto e reflexivo, de constante disputa e negociação" ${ }^{\prime 2}$, de maneira que, citando Jean Cohen, a partir de tal modelo produtivista de autorrealização "a liberdade tende a ser sacrificada em nome da abundância" ${ }^{\prime \prime}$. O juízo mais positivo que Melo dirige ao autor de $\mathrm{O}$ Capital é que este, em sua obra juveníssima (i.e. na Crítica da filosofia do direito de Hegel e em Sobre a questão judaica), teria ampliado o conceito do político de maneira que diga também respeito "aos processos sociais que residem na base econômica da sociedade" ${ }^{\prime \prime}$, embora no decorrer de sua obra ele tenha cedido à tendência de "reduzir a interação política à instrumentalidade das relações de classe" ${ }^{\prime \prime}$. Melo não apenas apresenta e critica a concepção de emancipação de Marx, mas também indica uma alternativa: com a distinção habermasiana de interação e trabalho, segundo ele, seria possível entender também a dimensão simbólica (e não somente a produtiva) da ação. Enquanto o trabalho se caracteriza por ser uma ação não linguística, estratégica (i.e. diz respeito a fins), a interação é uma ação linguística e comunicativa (sendo assim um processo reflexivo), dependendo da "cooperação e do assentimento livre de coerção"6. Portanto, sempre segundo o autor, na dimensão simbólica poderia ser encontrado um ideal emancipatório que não seria caracterizado pelo reducionismo economicista típico da dimensão estratégica. Sem tal distinção não seria mais possível "uma compreensão da dinâmica política em que as condições da emancipação social se encontrem em disputa"7.

O problema relativo ao próprio ideal emancipatório é comum às duas tradições que se inspiram em Marx, mas isto não as torna iguais. O paradigma revolucionário não só fracassou, uma vez que o proletariado não conseguiu realizar o ideal de uma sociedade emancipada (mesmo onde tenha conseguido fazer a revolução ou onde partidos supostamente defensores dele alcançaram as posições de comando), como tampouco conseguiu deixar um legado. $\mathrm{O}$ mesmo não ocorreu

2. MELO, R. Marx e Habermas. Teoria crítica e os sentidos da emancipação. São Paulo: Saraiva, 2013, p.137.

3. Idem, p. 126.

4. Idem, p. 140.

5. Idem, p. 141.

6. Idem, p. 179.

7. Idem, p. 186. 
com o paradigma reformista. Este, ao abandonar "a perspectiva dogmática da luta de classes", "a visão holista da sociedade" e "a falsa atitude diante do Estado democrático de direito" ${ }^{18}$, contribuiu para a universalização dos direitos civis e para a implementação de políticas redistributivas. No entanto, a limitação da concepção emancipatória dos reformistas, cujo ideal seria tão só "a humanização do trabalho", acaba por desconsiderar os "conflitos e potenciais emancipatórios não limitados à lógica redistributiva" ${ }^{\prime 10} \mathrm{e}, \mathrm{com}$ isso, torna-se insensível para o crescimento da burocracia estatal, assim como do paternalismo inerente a ela, decorrentes da forma centralizadora do Estado de BemEstar social. Particularmente interessante, na reconstrução de Melo, é que ele nota que não só há um engessamento da democracia pelo fato da cidadania ser "meramente distribuída como benefícios garantidos pela burocracia do Estado"11, como também que ficam cada vez mais claras as dificuldades da "manutenção do crescimento capitalista implementada por vias intervencionistas" ${ }^{\prime 12}$, isto é, que o próprio custo econômico do Estado de Bem-Estar social torna-se um fardo demasiado pesado, um fardo que o próprio capitalismo, gerido em grande parte pela intervenção político-governamental, não consegue mais suportar.

A última parte da narrativa trata, justamente, da tentativa de superar aquilo que Melo identifica como o dilema paralisante das forças críticas, a saber, a alternativa entre reforma e revolução. Para tanto, segundo o autor, é preciso o abandono tanto da "utopia de uma sociedade do trabalho" quanto de seu correlato, o paradigma produtivista. Na verdade, os novos movimentos sociais (e o autor elenca: os movimentos dos direitos civis, dos pacifistas, dos estudantes, das feministas, dos gays, dentre outros) alargaram o escopo de reivindicações, trazendo ao âmbito do político diversas demandas que não mais se enquadravam nos limites estreitos de uma esquerda que se ocupava unicamente da luta pela "supressão completa do capitalismo"13 ou, se resignada, que se engajava em sua reforma. Com a pluralidade das
8. Idem, p. 191.
9. Idem, p. 192.
10. Idem, p. 191.
11. Idem, p. 225.
12. Idem, p. 224.
13. Idem, p. 271. 
demandas e a nova realidade social do capitalismo tardio seria preciso, sempre conforme o autor - e quase sempre conforme Habermas também -, a substituição da própria orientação da crítica: ela não mais busca a sociedade emancipada, uma vez que "sociedades complexas e pluralistas (...) inviabilizariam a imagem de uma sociedade tomada em seu todo"14, em vez disso elas almejariam formas de vida emancipadas. Mas a narrativa triunfante que conduz de Marx a Habermas e seus sucessores, em que os déficits de cada estágio da teoria crítica são sanados pela etapa posterior, encontra, tal como Hegel ao se deparar com a plebe, um obstáculo talvez intransponível: a própria democracia vem perdendo sua vitalidade, uma vez que engessou a participação democrática em canais institucionalizados e limitou "as possibilidades de formação espontânea da opinião pública e da vontade coletiva"15. $\mathrm{O}$ autor, no entanto, parece não ver isto como algo que ponha em cheque o projeto da democracia deliberativa e insiste que é preciso um novo engajamento político que respeite as regras do jogo democrático e reconheça a legitimidade do poder existente uma vez que todos "consentiram com tal resolução uma vez que puderam formar a opinião, avaliar as questões envolvidas e contribuir na tomada de decisão ${ }^{\prime \prime 16}$.

\section{A crítica}

Antes das críticas, o elogio. O mínimo a ser dito é que a obra contém inúmeras virtudes. Apesar de não concordar, pelos motivos que exporei a seguir, com a argumentação geral de Melo, reconheço a grande pertinência do tema e a grande erudição com o qual é tratado. $\mathrm{O}$ autor apresenta uma literatura em grande parte desconhecida ao público brasileiro e trata com desenvoltura não somente o grande número de obras exegéticas sobre as teorias analisadas como também um amplo referencial histórico-sociológico que lida com as transformações da sociedade desde a época de Marx até os nossos dias. No entanto, a opção metodológica pela história dos efeitos (a), uma interpretação demasiado tradicional e restrita de Marx (b), e um otimismo exagerado em relação às potencialidades contidas na teoria habermasiana e de certo número de seus sucessores (c) faz com que, a meu

\footnotetext{
14. Idem, p. 295.

15. Idem, p. 316.

16. Idem, p. 319.
} 
ver, o livro aqui debatido não alcance plenamente o objetivo que ele mesmo propõe: o de renovar a teoria crítica e o de obter a "compreensão profunda do presente" do qual falava Horkheimer.

\section{a) História dos efeitos?}

Melo defende a abordagem da história dos efeitos como a adequada para lidar com os problemas da história da filosofia, uma vez que ela permite "perceber nuances, potencialidades e limitações de uma teoria que só se explicitam a partir da história de seus efeitos ${ }^{117}$. Contudo, a história dos efeitos precisaria se defrontar com uma série de questões bem mais ampla do que aquela que efetivamente enfrenta, ao menos no caso desta obra. Para começar, é praticamente impossível fazer um panorama da totalidade dos efeitos de uma obra como a de Marx, uma vez que ela recebeu interpretações inteiramente díspares e motivou cursos de ação totalmente opostos. Basta lembrar que sua obra foi usada tanto para legitimar os regimes do socialismo realmente existente quanto para criticá-los e questioná-los; tanto para justificar as opções em geral autoritárias dos partidos comunistas oficiais como os modelos libertários dos movimentos autonomistas; houve quem a leu como um advogado da causa do trabalho e houve quem a leu como um defensor da preguiça (opção esta do próprio genro de Marx, Paul Lafargue). O autor, infelizmente, desconsidera tal pluralidade e dedica atenção apenas a duas tendências predominantes do movimento operário ${ }^{18}$. Isto aponta para um segundo problema: a história dos efeitos precisa tratar de forma mais refinada a complexa relação que há entre teoria e prática. Se é certo que Marx escreveu sua obra sempre em contato próximo com os movimentos dos trabalhadores, é igualmente certo que esta não foi apenas a expressão teórica daqueles, mas sempre manteve uma tensão e mesmo uma distância crítica com relação a eles. Assim, seria necessário mostrar como se dá esta relação, reconstruindo as tendências predominantes do movimento operário e mostrando como Marx se relacionou com elas. Há, por assim dizer, um abismo entre a obra marxiana e

17. Idem, p. 340 .

18. Algo que vai contra a sua própria observação de que "a teoria crítica não pode reproduzir acriticamente a voz do movimento social. Marx não havia feito isso" (MELO, R. Marx e Habermas. Teoria crítica e os sentidos da emancipação, p. 268). 
doutrinas por ela inspiradas que não é transposto, tampouco se constrói os meios para fazê-lo. A história dos efeitos, assim, é transformada apenas num rótulo para legitimar uma interpretação que ignora boa parte das nuances e ambiguidades do texto original, pois nada disso importa, mas sim o modo como Marx foi supostamente lido. Ora, a teoria crítica tem pouco a ganhar escolhendo metodologias que apenas reforçam as tendências dominantes, seja na sociedade, seja na exegese de um autor. Antes, sua função deveria ser a de escovar a história a contrapelo, também no caso da história da filosofia.

Ademais, a opção pela história dos efeitos é deveras parcial, sendo aplicada a Marx, mas não a Habermas. Por quê? Não se encontra explicação, mas a exegese da obra habermasiana é feita em geral com a intenção de mostrar as melhores potencialidades nela contidas ou aquilo que seria a sua "verdadeira teoria", em vez de explicá-la a partir dos efeitos que ela tem causado. E há de se lastimar isto, sobretudo porque, salvo engano, Habermas parece um tanto descuidado em suas intervenções. Não é à toa que o Partido Popular espanhol, e mais especificamente o então presidente José Maria Aznar, mostrou grande entusiasmo pelo conceito de "patriotismo constitucional", um conceito que lhe pareceu feito sob medida para sustentar políticas xenofóbicas sem ter que perder a pose liberal ${ }^{19}$. Também as fortes críticas ao paternalismo inerente ao Estado de Bem-Estar socialdemocrata, por mais corretas que sejam na maioria das vezes (e reconstruídas com grande esmero no livro aqui comentado), ao olhar retrospectivo do presente parecem ter errado o alvo: num momento em que a teoria deveria ter defendido o legado do Estado de Bem-Estar social diante da ameaça iminente de seu desmonte retrógrado, ela se junta ao coro dos críticos buscando mostrar antes as deficiências daquele que está saindo de cena do que as daquele que está entrando: o Estado centauro neolibera ${ }^{20}$. Por fim, também no atual debate sobre a argu-

19. Cf. ZIZEK, S. O filósofo estatal. Folba de São Paulo, 24 de Março de 2002, disponível em: < http://www1.folha.uol.com.br/fsp/mais/fs2403200206. htm>.

20. O conceito de Estado centauro é desenvolvido por Loïc Wacquant em "Três etapas para uma antropologia histórica do neoliberalismo realmente existente". Wacquant afirma que o Estado centauro: "exibe rostos opostos nos dois extremos da estrutura de classes: ele é edificante e 'libertador' no topo, onde atua para alavancar os recursos e expandir as opções de vida dos detentores de capital econômico e cultural; mas é penalizador e restritivo na base, 
mentação religiosa na política, as sugestões de Habermas costumam dar aval, ou ao menos assim têm sido interpretadas por grande parte de seus leitores (que é o único que importa na história dos efeitos), aos desmandos da maioria religiosa ${ }^{21}$.

\section{b) Por uma outra interpretação de Marx}

Em sua interpretação da obra marxiana, Melo, em geral, apenas avaliza a interpretação de Habermas, segundo a qual Marx teria ficado preso ao paradigma produtivista, ao âmbito do trabalho, à filosofia do sujeito ou da consciência. No entanto, a interpretação habermasiana da obra de Marx é claramente deficitária, e isto fica evidente a partir da análise das poucas passagens em que o teórico de Düsseldorf se aproxima do texto marxiano, em vez de comentá-lo à distância ${ }^{22}$. Melo tenta, assim, corroborar textualmente uma crítica cuja condição de existência parece ser esta não familiaridade. Neste aspecto, ao menos, o resultado é pouco promissor, uma vez que o autor parece comprometido de antemão a ler Marx a partir da interpretação habermasiana e a não romper com esta de jeito algum. Um exemplo disso é o tratamento dado à categoria trabalho, categoria esta que, por sinal, desempenha uma função proeminente na leitura de Melo. Para ele, o

quando se trata de administrar as populações desestabilizadas pelo aprofundamento da desigualdade e pela difusão da insegurança do trabalho e da inquietação étnica. O neoliberalismo realmente existente exalta o 'laissez faire et laissez passer' para os dominantes, mas se mostra paternalista e intruso para com os subalternos" (WACQUANT L. Três etapas para uma antropologia histórica do neoliberalismo realmente existente. Caderno CRH, v. 25, n. 66, 2012, p. 512).

21. Uma boa discussão sobre este assunto se encontra no debate entre Pinzani (2009) e Araújo (2009). In: PINZANI, A. et al. O Pensamento vivo de Habermas. Uma visão interdisciplinar. Florianópolis: Nefipo, 2009, p. 211-228.

22. Para citar apenas um exemplo: em Teoria do agir comunicativo Habermas fala, se referindo a O Capital, que "o valor de uso está para o valor de troca assim como a essência está para a aparência" (HABERMAS, J. Teoria do agir comunicativo. São Paulo: Martins Fontes, 2012, p. 614), provavelmente querendo dizer que "o valor está para o valor de troca assim como a essência está para a aparência", correção que por si só já impede a rejeição em bloco por parte de Habermas das obras de Backhaus, Krahl, Reichelt e outros. É conveniente recordar que tais categorias (valor, valor de troca, valor de uso) são termos-chave da crítica da economia política de Marx. 
conceito de "trabalho abstrato" significa, grosso modo, o trabalho remunerado, típico do capitalismo industrial, o qual é contraposto ao "trabalho concreto" que seria aquele típico dos artesãos ou da sociedade feuda123. Ora, salvo engano, "trabalho abstrato" e "trabalho concreto" são duas dimensões do trabalho que produz mercadorias, o primeiro gerando valor e o segundo criando valor de uso (não sendo, portanto, dois tipos de trabalhos distintos, mas duas facetas de um mesmo trabalho, tal como se caracteriza na sociedade capitalista quando se generaliza a forma-mercadoria) ${ }^{24}$. Melo defende a tese segundo a qual o trabalho seria, para o autor socialista, "a atividade humana mais essencial" ${ }^{\prime 25}$. No entanto, é preciso perceber que em diversos casos isto não ocorre. Assim, por exemplo, ele diz na Introdução à Para a crítica da economia política que "o trabalho é uma categoria (...) moderna" ${ }^{126}$, e em inúmeros textos a sociedade comunista é vista como uma na qual tal atividade é abolida (caso de A Ideologia alemã) ou reduzida a uma quantia mínima (caso dos Grundrisse e de O Capital). Ora, se o trabalho fosse realmente visto como a atividade humana essencial por Marx, não seria de se esperar que a sociedade emancipada se caracterizasse por fazer ao máximo tal atividade, e não por reduzi-la ao mínimo? Não seria um quid pro quo falar de uma "utopia da sociedade do trabalho" cujos partícipes não trabalham? Diversos autores têm apontado para ambiguidades da categoria trabalho no texto marxiano, e de fato algumas vezes é possível encontrar nele esta compreensão atemporal de trabalho, quase metafísica, à qual Melo se atém. Esta, por sinal, é a interpretação do marxismo tradicional e as críticas feitas por Melo seriam, a meu ver, plenamente pertinentes, caso se dirigissem tão somente a ela. Se tivesse por alvo ou interlocutor uma corrente exegética da obra de Marx como a da Escola de Budapeste (da "onto-

23. MELO, R. Marx e Habermas. Teoria crítica e os sentidos da emancipação, pp. 34, 108-9, 182. Habermas também interpreta assim tais categorias em: HABERMAS, J. A Crise do Estado de bem-estar social e o esgotamento das energias utópicas. Novos Estudos CEBRAP, n. 18, 1987, pp. 105-6.

24. MARX, K. O Capital. Livro I, Volume I. São Paulo: Nova Cultural, 1985, pp. 49-53.

25. MELO, R. Marx e Habermas. Teoria crítica e os sentidos da emancipação, p. 123.

26. MARX, K. Introdução à Para a crítica da economia política. In: Para a crítica da economia política; Salário, preço e lucro; $O$ rendimento e suas fontes; A economia vulgar. São Paulo: Abril Cultural, 1982, p. 16. 
logia do ser social" do Lukács tardio), as deficiências que o autor elenca poderiam, acredito, ser facilmente corroboradas textualmente. Porém, na medida em que tem por interlocutores autores que rompem com o marxismo tradicional, como é o caso, no âmbito internacional, de Moishe Postone, de Helmut Reichelt, de Roman Rosdolsky, e no âmbito nacional de Ruy Fausto, de Jorge Grespan e de Paulo Arantes, Melo acaba por direcionar a crítica para teóricos cujo ideal de emancipação em nada se assemelha a esta religião do trabalho por ele reconstruída.

Ademais, quando Melo afirma que Marx fica preso ao paradigma da produção e à filosofia da consciência, ele está projetando em sua obra a distinção habermasiana de trabalho e interação e dizendo que o seu projeto de crítica da economia política está inserido no primeiro e que exclui o segundo. Mas esta é uma boa chave para pensar a obra marxiana? Acredito que não. A crítica da economia política inicia justamente pela análise da mercadoria, a forma elementar da riqueza nas sociedades capitalistas. Mas a mercadoria não é o produto criado na relação do homem isolado com a natureza, e sim, basicamente, uma forma de relação social, uma vez que ela é feita de antemão visando a troca. $\mathrm{O}$ intercâmbio mercantil, analisado à exaustão na obra marxiana, é uma forma de interação, intersubjetiva, linguística e simbólica, embora, como grande parte das interações intersubjetivas realmente existentes não seja realizada a partir da "cooperação e o assentimento livre de coerção dos participantes ${ }^{\prime \prime 27}$ que caracteriza a interação habermasiana segundo Melo (uma vez que pressuporia o "entendimento que habita no interior do próprio medium linguístico ${ }^{128}$, pressuposto este só encontrado idealmente). Mesmo o processo de trabalho é analisado na crítica da economia política marxiana como um processo intersubjetivo, permeado pela linguagem, sujeito a acordos, conflitos e regulações, e não como uma relação de sujeito-objeto, como Melo afirma ${ }^{29}$. O mesmo se passa com a acusação de "economicismo". Melo discorre ao longo de várias páginas a tese de que Marx projeta as relações econômicas em todas as outras esferas, que ele compreende toda a sociedade a partir da perspectiva econômica e que é incapaz

27. MELO, R. Marx e Habermas. Teoria crítica e os sentidos da emancipação, p. 179.

28. Idem, ibidem.

29. Cf. Idem, p. 180. 
de perceber como se dá a ação comunicativa que supostamente seria determinante na esfera política. No entanto, Melo dedica pouca atenção para a questão do que significa o subtítulo da obra magna de Marx, "crítica da economia política" e, por conseguinte, ao próprio projeto teórico marxiano. Salvo engano, Marx não se propõe a fazer uma análise oniabarcante da sociedade ou oferecer um quadro ou gramática de todos os tipos de conflitos sociais (embora o marxismo tradicional, que se constitui como uma visão de mundo que pretende explicar tudo a partir da obra de Marx, por vezes faça isto), mas sim a analisar o modo de produção capitalista e criticá-lo de forma imanente $^{30}$. A tese de Marx é que o capitalismo cria uma nova forma de dominação na qual o processo econômico ganha vida própria e passa a sujeitar os indivíduos, transformando-os em meras engrenagens de seu mecanismo de autovalorização. Portanto, a crítica de Marx é que o modo de produção capitalista justamente transcende a esfera da economia, dissemina-se também em outros âmbitos, criando uma nova forma de dominação. Marx critica a sociedade capitalista precisamente por ela ser economicista, por ela estar presa ao paradigma da produção. Neste ponto parece haver uma confusão entre a dimensão normativa e a dimensão descritiva tanto da obra de Marx (de modo que aquilo que o autor de $O$ Capital descreve como o estado existente das coisas, um mundo dominado pelo paradigma da produção e pela ótica da economia, é visto como a sociedade ideal socialista) quanto na exegese da sociedade atual (em que o mundo parece não mais se pautar por um ideal produtivista, já tendo saído da sociedade do trabalho, simplesmente porque gostaríamos que este fosse o caso), ou ao menos não vejo como alguém possa defender, na era do precariado, que a sociedade do trabalho chegou ao $\mathrm{fim}^{31}$.

30. Não deixa de ser curioso observar que Melo, seguindo Cohen, faz uma crítica a Marx que o próprio Marx havia feito a outros críticos de sua época, a saber, a de achar que só os proletários sofriam nas condições atuais. Cito um trecho de Sobre o suicídio, de Marx: "A pretensão dos cidadãos filantropos está fundamentada na ideia de que se trata apenas de dar aos proletários um pouco de pão e de educação, como se somente os trabalhadores definhassem sob as atuais condições sociais, ao passo que, para o restante da sociedade, o mundo tal como existe fosse o melhor dos mundos" (MARX, K. Sobre o suicídio. São Paulo: Boitempo, 2006, p. 22).

31. Cf. MELO, R. Marx e Habermas. Teoria crítica e os sentidos da emancipação, p. 263. Diversas outras afirmações ao longo do livro parecem um tanto 
Por fim, por mais interessante que possa ser a concepção do âmbito político do juveníssimo Marx, uma teoria crítica adequada para lidar com os problemas contemporâneos certamente tem muito mais a ganhar com releituras de O Capital e do restante da obra tardia do autor. Postone, por exemplo, não tem sido discutido por ter conseguido oferecer uma "salvação" de Marx ou uma interpretação autêntica do mesmo (como Melo sugere ${ }^{32}$ ), mas basicamente por conseguir esclarecer, a partir da obra marxiana, alguns aspectos da dinâmica do capitalismo atual, tal como a criação de uma população supérflua que não consegue mais ser inserida na esfera da produção. Nesse sentido, Melo, que justamente busca pensar uma teoria crítica adequada para o presente, não dá atenção ao fato de que nos últimos trinta ou quarenta anos as desigualdades materiais cresceram de forma abissal, de forma que é preciso urgentemente repensar a primazia das "demandas por reconhecimento de diferenças culturais" ${ }^{\prime \prime 3}$, e tampouco atribui importância à circunstância de que, no mundo pós-2008, os questionamentos acerca do capitalismo retornaram e, tão cedo, não deverão ser relegados a segundo plano ${ }^{34}$.

descontextualizadas hoje em dia, como, por exemplo, esta: "Mesmo que uma crise econômica pudesse ocorrer algum dia, o argumento que defendia tanto a sua inevitabilidade quanto sua determinação econômica se enfraquece sensivelmente" (p. 222). Ora, a crise atual é antes econômica do que de legitimação.

32. Cf. Idem, p. 341.

33. Idem, p. 42. Não defendo, de forma alguma, que as demandas culturais não tenham muita importância ou mesmo que devam estar subordinadas a outras reivindicações. Apenas constato, seguindo Nancy Fraser, que uma nova esquerda precisa conciliar estes tipos de demandas em vez de seguir opondo uma à outra como ela tem feito, de forma infrutífera, nos últimos decênios. Aliás, penso que o verdadeiro "dilema paralisante" nas forças críticas é justamente este que opõe as demandas por redistribuição às demandas por reconhecimento.

34. Como observa Fraser: "a crítica da sociedade capitalista, crucial para as primeiras gerações, quase desapareceu da agenda da teoria crítica. A crítica centrada na crise capitalista, especialmente, foi declarada reducionista, determinista e ultrapassada. Hoje tais verdades estão em frangalhos" (FRASER, N. Marketization, social protection, emancipation: toward a neo-Polanyian conception of capitalist crisis. In: CALHOUN, C. e DERLUGUIAN, G. (ed.). Business as usual: The roots of the global financial meltdown. New York: New York University Press, 2011, p. 137). 


\section{c) A construção de uma teoria crítica da sociedade adequada ao presente}

Minha discordância com Melo, no entanto, não se limita à (pouca) importância dada ao pensamento marxiano na tentativa de atualizar a teoria crítica da sociedade e oferecer um diagnóstico de época adequado ao presente, mas diz respeito também ao quanto a teoria habermasiana pode fazê-lo. Melo praticamente aceita como pressuposto que a teoria de Habermas é apta para lidar com os problemas de nosso tempo. Ao contrário dele, acredito que, apesar de Habermas ainda estar vivo e produzindo freneticamente, sua teoria está baseada em um diagnóstico obsoleto (ao menos no que tange a mediação entre a esfera política e a econômica, tal como reconstruído no livro aqui comentado) e que só tomando grande distância deste diagnóstico poderemos ver o que em sua teoria não está totalmente ultrapassa$\mathrm{do}^{35}$. Dito de forma muito direta, a teoria habermasiana foi forjada em uma situação social muito peculiar e excepcional, a do Estado de Bem-Estar social amplo e vigoroso que esteve vigente na Alemanha do pós-guerra em uma época de imensa prosperidade econômica que se refletiu em melhorias generalizadas no padrão de vida. Hobsbawn, na Era dos extremos, designa tal período como "a era de ouro" do de resto catastrófico "breve século XX", embora ressalte que, se é certo que praticamente toda a população europeia (ocidental) gozou das benesses dessa época, nem todo o resto do mundo teve tal sorte ${ }^{36}$. Na época, estava bem assentada a crença de que tais benesses seriam duradouras e se disseminariam aos poucos pelo mundo, e tal crença estava tão arraigada no pensamento habermasiano que no término do artigo "trabalho e interação" ele afirmava que "apesar da fome reinar ainda sobre dois terços da população mundial, a eliminação da fome já não é nenhuma utopia no sentido pejorativo" ${ }^{1 / 37}$. Se lhe parecia que a fome e a miséria poderiam estar com os dias contados, o mesmo não ocorria a respeito da servidão e da humilhação, e por isso Habermas

35. A meu ver, o grande legado habermasiano foi a ênfase colocada nos procedimentos. Seria um grande retrocesso voltar a dar atenção somente aos resultados das políticas sem levar em consideração também o modo como são tomadas as decisões e como elas são postas em prática.

36. Cf. HOBSBAWN, E. Era dos extremos: o breve século XX. São Paulo: Companhia das letras, 1995, pp.253-282.

37. HABERMAS, J. A Crise do Estado de bem-estar social e o esgotamento das energias utópicas. Novos Estudos CEBRAP, n. 18, 1987, p. 42. 
se dirige de forma cada vez mais enfática aos conflitos que não podem ser chamados de redistributivos ou, em seu linguajar, não dizem respeito à esfera do trabalho. É evidente que nem o mais otimista dos analistas sociais acredita hoje que a fome possa acabar num futuro próximo. Na verdade, a quantia de pessoas passando fome no mundo se estabilizou em um patamar altíssimo (870 milhões de pessoas, segundo os dados da FAO em 2013) e é muito provável que, em consequência da atual crise econômica e também por causa do aquecimento global, volte a aumentar. Quando o Estado de Bem-Estar social entra em crise, ao longo dos anos oitenta, Habermas endossa o coro liberal que vê no excesso de regulação sobre o mercado uma patologia. $\mathrm{Na}$ verdade, ele chega mesmo a afirmar coisas que se parecem muito mais com a pregação neoliberal do que com a teoria crítica, tal como a tese de que sociedades complexas como as nossas "não podem se reproduzir se não deixam intacta a lógica de auto-orientação de uma economia regulada pelos mercados ${ }^{\prime \prime 38}$. É difícil pensar numa afirmação que pode ser considerada mais refutada do que essa pelos acontecimentos dos últimos tempos. Uma teoria crítica hoje não pode deixar de lado o mercado capitalista e os malefícios dele decorrentes como se fossem danos necessários à autorreprodução material da sociedade. Isto nos afasta terminantemente do diagnóstico habermasiano. Melo, contudo, cita a frase recém referida de forma positiva, anuindo com seu conteúdo ${ }^{39}$.

O fato de endossar sem mais o datado diagnóstico de Habermas se reflete em diversos âmbitos do livro de Melo. Assim, com toda razão, ele diz que os "novos movimentos sociais" fazem demandas que se diferenciam daquelas do movimento operário tradicional, mas parece considerar como novos movimentos apenas aqueles de meados do século passado cujas reivindicações básicas eram por direitos civis.

38. HABERMAS, J. O que significa socialismo hoje? Novos Estudos CEBRAP, n. 30, 1991, p. 56. Esta afirmação é problemática não apenas enquanto prescrição, mas igualmente como descrição do que ocorre. O mercado neoliberal não é marcado por uma ausência do Estado, mas pela completa subordinação das sempre presentes intervenções estatais às finalidades mercantis (para uma análise mais adequada a respeito disso, cf. WACQUANT L. Três etapas para uma antropologia histórica do neoliberalismo realmente existente. Caderno CRH, v. 25, n. 66, 2012).

39. MELO, R. Marx e Habermas. Teoria crítica e os sentidos da emancipação, p. 250. 
Mas será que não surgiu nada de novo neste ínterim? Os dias de ação global na década de noventa, assim como o Occupy Wall Street ou mesmo o Movimento Passe Livre têm demandas muito distintas daquelas. As demandas de tais movimentos não podem encontrar espaço na crença de que a emancipação diz respeito apenas a formas de vida, e não a própria esfera da sociedade, uma vez que ou todos vivemos numa cidade na qual o transporte público seja eficiente e voltado para as pessoas, não para o lucro, ou ninguém pode ver-se emancipado do trânsito caótico que inferniza a vida dos habitantes de qualquer cidade mediana ou maior do que isso, exceto talvez os riquíssimos que desfilam pelo céu em seus helicópteros (aliás, isto já era válido para então, pois também a emancipação do medo da possibilidade de eclosão de uma guerra nuclear só pode ser coletiva, ou melhor, universal $)^{40}$.

Ademais, diversas vezes ele afirma que o ideal socialista clássico perdeu seu referencial concreto, que as ideias precisam estar ancoradas de alguma forma na realidade. Mas isto não é válido, infelizmente, também para o ideal de democracia deliberativa de Habermas? A distância que separa nossas democracias realmente existentes da verdadeira democracia deliberativa habermasiana não é tão gigantesca quanto aquela que os marxistas mais bem intencionados afirmavam haver entre o socialismo realmente existente e o verdadeiro ideal socialista? Melo acredita que não. Isto porque a democracia deliberativa não é apenas um experimento mental, mas algo latente nas nossas democracias de massa. Mas isto nos coloca num dilema em que é difícil decidir qual alternativa consegue ser pior: ou aceitamos o sistema político atual como legítimo, como democrático, e afirmamos assim que a democracia realmente existente já é a democracia deliberativa, mas aí temos de reconhecer que um sistema político incapaz de dar fim mesmo à fome (e outras formas extremas de sujeição) em meio a uma abundância material nunca antes vista em nada é emancipatório; ou, ao contrário, afirmamos que o sistema político atual é ilegítimo, uma pálida imitação da verdadeira democracia, mas com isso apelamos

40. A emancipação sempre se refere a algo de que é preciso libertar-se. Insistir em uma emancipação da sociedade significa, portanto, que há coações sociais que impossibilitam a independência e autonomia das pessoas em determinada sociedade. Tais coações podem ser econômicas (como o agente capital na crítica da economia política de Marx, que faz com que toda a sociedade se subordine ao imperativo do crescimento econômico), políticas, urbanas etc. 
para um ideal de modo algum ancorado na realidade. Ora, o ideal habermasiano é sem dúvida bonito e digno de valor, mas tão idealizado e abstrato quanto o projeto kantiano para a paz perpétua.

Por fim, voltando à questão da imbricação entre economia e política, Melo tenta, em seu livro, mostrar que o dilema reforma versus revolução não faz mais sentido nos dias de hoje, pois a esquerda cai em impasses insanáveis tanto ao tentar suprimir o capitalismo quanto ao tentar reformá-lo. A opção habermasiana, contudo, mostra impasse ainda maior, verdadeiro cul de sac: é preciso, ao mesmo tempo, controlar o sistema econômico e deixar intacta a sua lógica de autorregulação; impedir a colonização de outras esferas pelos imperativos econômicos sem, no entanto, colocar em risco a própria saúde do capitalismo. Ora, isto é uma miragem. Diante do dilema reforma/revolução não há terceira via, salvo sem deixar de ser esquerda, i.e., sem deixar de combater as desigualdades sociais, e resignar-se ao capitalismo atualmente existente como se este fosse o melhor dos mundos possíveis. Ao fim e ao cabo é o que parece fazer Habermas. Parece-me não haver escolha mais equivocada.

\section{Referências}

ARAÚJO, L. B L. Habermas e a religião na esfera pública: um breve ensaio de interpretação. In: PINZANI, A. et al. O Pensamento vivo de Habermas. Uma visão interdisciplinar. Florianópolis: Nefipo, 2009, p. 229-244.

FRASER, N. Marketization, social protection, emancipation: toward a neo-Polanyian conception of capitalist crisis. In: CALHOUN, C. e DERLUGUIAN, G. (ed.). Business as usual: The roots of the global financial meltdown. New York: New York University Press, 2011, pp. 137-157.

HABERMAS, J. Teoria do agir comunicativo. São Paulo: Martins Fontes, 2012.

A Crise do Estado de bem-estar social e o esgotamento das energias utópicas. Novos Estudos CEBRAP, n. 18, 1987, p. 103-114.

O que significa socialismo hoje? Novos Estudos CEBRAP, n. 30,1991, p. $43-61$.

Trabalho e interação. In: Técnica e ciência como "ideologia". Lisboa: Edições 70, 1987.

HOBSBAWN, E. Era dos extremos: o breve século XX. São Paulo: Companhia das letras, 1995. 
Marx e Habermas: Teoria crítica e os sentidos da emancipação, de Rúrion Melo

MARX, K. Introdução à Para a crítica da economia política. In: Para a crítica da economia política, Salário, preço e lucro, O rendimento e suas fontes, A economia vulgar. São Paulo: Abril Cultural, 1982.

O Capital. Livro I, Volume I. São Paulo: Nova Cultural, 1985. Sobre o suicídio. São Paulo: Boitempo, 2006.

MELO, R. Marx e Habermas. Teoria crítica e os sentidos da emancipação. São Paulo: Saraiva, 2013.

PINZANI, A. Fé e saber? Sobre alguns mal-entendidos relativos a Habermas e à religião. In: PINZANI, A. et al. O Pensamento vivo de Habermas. Uma visão interdisciplinar. Florianópolis: Nefipo, 2009, p. 211-228.

WACQUANT L. Três etapas para uma antropologia histórica do neoliberalismo realmente existente. Caderno CRH, v. 25, n. 66, 2012, p. 505-518.

ZIZEK, S. O filósofo estatal. Folha de São Paulo, 24 de Março de 2002, disponível em: < http://www1.folha.uol.com.br/fsp/mais/ fs2403200206.htm>.

Recebido em 15.05.2014

Aceito em 03.11.2014 